NO.10 Journal of Petroleum Research \& Studies ( JPR \& S)

\title{
New Development in Catalytic Reforming Process to Produce
}

\section{High Octane Gasoline}

Khalid A. Sukkar*; Hayam M. Abd Al-Raheem**; Layth S. Sabry**; Lattif A. Resym***

*Petroleum Engineering Department-University of Misan / Misan - I raq **Department of Chemical Engineering - University of Technology / Baghdad Iraq

*** Labrotaries Depertment Al-Dura Refinery / Baghdad - Iraq

\section{$\underline{\text { Abstract }}$}

In this work, improved catalytic reforming reaction was carried out through using reaction promoters $\mathrm{Sn}$, in and Ge. Four types of catalysts were prepared: $\mathrm{Pt} / \mathrm{HY}, \mathrm{Pt}-\mathrm{Sn} / \mathrm{HY}$, and Pt-Sn-In/HY, and Pt-Sn-Ge/HY. The weight percentage of metals were $0.5 \%$ for Pt and $0.1 \%$ for each of $\mathrm{Sn}$, In and Ge.

The performances of catalysts (activity, selectivity and catalyst stability) were studied using Iraqi heavy naphtha of Al-Dura refinery (Baghdad) as feedstock. The catalytic reforming unit consisted of a vertical tubular stainless steel reactor of $20 \mathrm{~mm}$ internal diameter, $30 \mathrm{~mm}$ external diameter and $680 \mathrm{~mm}$ height. The operating pressure was atmospheric, and the operating temperatures varied between 425 to $525{ }^{\circ} \mathrm{C}$. For all experimental runs: the weight hourly space velocity WHSV $=2$, the catalyst amount $=50 \mathrm{~g}$, and $\mathrm{H}_{2} / \mathrm{HC}$ ratio $=3$.

The results showed that the best reforming temperature over all four types of prepared catalysts was $475{ }^{\circ} \mathrm{C}$ which gave the highest conversion of heavy naphtha to high octane products (aromatics and branched isomers). It was concluded that the trimetallic catalyst $\mathrm{Pt}-\mathrm{Sn}-\mathrm{In} / \mathrm{HY}$ and $\mathrm{Pt}-\mathrm{Sn}-\mathrm{Ge} / \mathrm{HY}$ show high selectivity to 
NO.10 Journal of Petroleum Research \& Studies ( JPR \& S)

desired reforming products with $91.5 \%$ and $85 \%$ respectively. On the other hand, the Pt-Sn/HY and Pt/HY, catalysts show slectivities of $79 \%$ and $74 \%$ respectively.

The results indicated a clear increase in catalyst stability with high resistance to coke formation for catalysts promoted with In and Ge as a third metal. Also, it was noted that the production of aromatics and isomers are increased for both types of trimetallic catalysts Pt-Sn-In/HY, and Pt-Sn-Ge/HY under the same operating conditions.

Keywords: Heavy naphtha reforming; Pt/HY; Pt-Sn/HY; Pt-Sn-In/HY; and Pt-Sn-

$$
\text { Ge/HY catalysts. }
$$

الخلاصســة

في هذا البحث تم اعداد دراسـة لغرض تطوير عملية التهذيب بالعامل المساعد باستخدام مرقيات

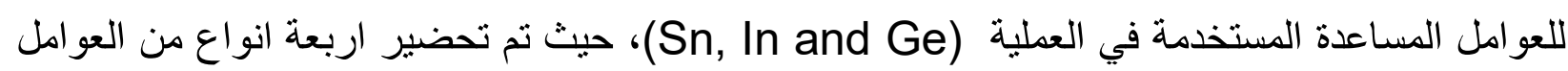

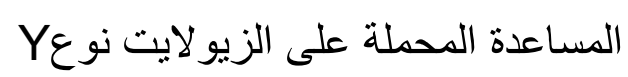

Pt/HY, Pt-Sn/HY, and Pt-Sn-In/HY, and Pt-Sn-Ge/HY و 0.1\% لكل من In Sn و . تم دراسة اداء العوامل المساعدة المحضرة باستخدام مسادة النفتـا العراقيـة الثقيلة (مصفى الدورة) كمادة اولية للعملية. تم الدراسة في منظومة مصنعة من الحديد المقاوم للصدى بأبعاد 20 و30 ملم للقطر الداخلي والخارجي للمفاعل وبطول 680 ملم. الضغط المستخدم كان

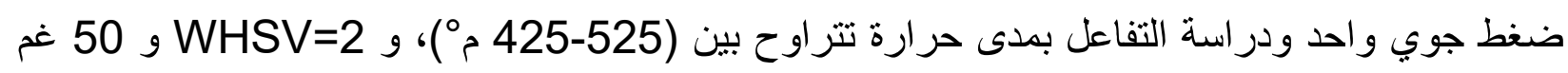

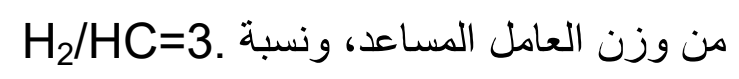

أظهرت النتائج أن أفضل حرارة للعوامل المساعدة المستخدمة كانت 475 مْ و التي أعطت أعلى نسبة تحول من النفا الثقلة للمركبات العطرية والايزومرات المتفرعة التي تمتلك عدد اوكتاني عالي. أثتبت النتائج ان العو امل المساعدة ثلاثية المعدن نوع Pt-Sn-In/HY, and Pt-Sn-Ge/HY أعطت انتقائية

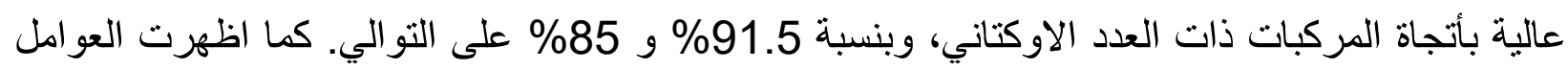

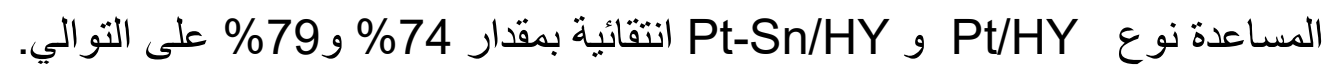


ومن جانب اخر اثبتت النتائج ان اضافة المعدن الثالث نوع الجرمانيوم والانيديوم نتج عنة استقرار عالي

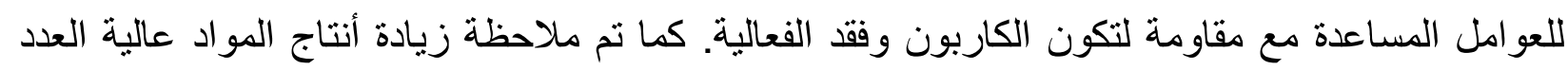

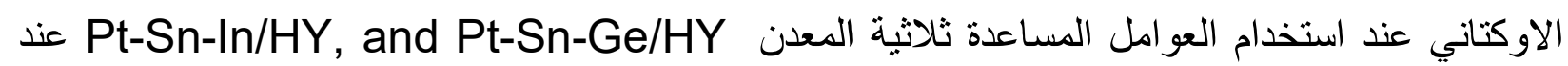
نفس الظروف التشغيلية.

\section{$\underline{\text { 1. Introduction }}$}

Catalytic naphtha reforming plays a major role in satisfying the demand for unleaded, high octane gasoline. Catalytic reforming generally is applied to a feedstock rich in paraffinic and naphthenic hydrocarbons and is effected through diverse reactions: dehydrogenation of naphthenes to aromatics, dehydrocyclization of paraffins, isomerization of paraffins and naphthenes, dealkylation of alkylaromatics and hydrocracking of paraffins to light hydrocarbons [1, 2]. The high octane gasoline is achived through a continouss improvement of the catalytic reforming process to formation of aromatics and branched chain paraffins [3, 4, and 5].

The reforming process is carried out over bifunctional catalysts which consist mainly of a metal phase ( $\mathrm{Pt}, \mathrm{Re}$, and $\mathrm{Ru}$ ) dispersed on an acidic support such as $\mathrm{Al}_{2} \mathrm{O}_{3}$. Usually, reforming reactions are accompanied by the formation of undesired carbonaceous compounds that deactivate the catalyst. This coke can have different crystalline structures, morphologies, and reactivities, depending on the specific reaction taking place and the reaction conditions $[1,6]$. Therefore, many types of metals are used as promoters to modify the catalysts and then to improve the process activity, selectivity and catalyst stability $[2,7,8]$.

Most of the catalysts that have been investigated in literature [7, 8, 9, and 10] were focused on improvement of activity and selectivity of reforming catalysts supported on $\mathrm{Al}_{2} \mathrm{O}_{3}$. Mazzieri et al. [7] performed experimental study on the PtRe-Sn trimetallic catalysts for naphtha reforming. Moreover, Mazzieri et al. [12] 
NO.10 Journal of Petroleum Research \& Studies ( JPR \& S)

investigated the deactivation and regeneration of the metal function of Pt-Re$\mathrm{Sn} / \mathrm{Al}_{2} \mathrm{O}_{3}-\mathrm{Cl}$ and $\mathrm{Pt}-\mathrm{Re}-\mathrm{Ge} / \mathrm{Al}_{2} \mathrm{O}_{3}-\mathrm{Cl}$ for catalytic naphtha reforming. On the other hand, Carlos et al. [13] studied the chemisorption of CO over mono-, bi- and trimetallic naphtha reforming catalysts containing $\mathrm{Pt}, \mathrm{Re}$ and $\mathrm{Sn}$ in the metallic function using (TPR). The CO chemisorption results indicate that it is possible to determine in an easy way the metallic dispersion of $\mathrm{Pt} / \mathrm{Al}_{2} \mathrm{O}_{3}$ monometallic catalysts and that the same method can be applied to measure the exposed Pt on bimetallic Pt-Re and Pt-Sn catalysts and trimetallic Pt-Re-Sn catalysts.

Maria et al. [14] studied the influence of gallium on the properties of Pt$\mathrm{Re} / \mathrm{Al}_{2} \mathrm{O}_{3}$ catalysts in naphtha reforming. They were found that the addition of $\mathrm{Ga}$ to the $\mathrm{Pt}-\mathrm{Re} / \mathrm{Al}_{2} \mathrm{O}_{3}$ catalyst diminishes its acidity (Bronsted and Lewis). Also, they concluded that for the $\mathrm{n}$-heptane reforming reaction the addition of $\mathrm{Ga}$ increases both catalyst stability and selectivity to aromatics, and with low light gases. Shahrazad et al. [15] developed a comprehensive experimental and a mathematical model for the reaction of catalytic reforming process. Two types of tri-metal catalysts supported on $\mathrm{Al}_{2} \mathrm{O}_{3}$ were prepared (Pt-Re-Sn/ $/ \mathrm{Al}_{2} \mathrm{O}_{3}$ and Pt-Ir-Sn/ $/ \mathrm{Al}_{2} \mathrm{O}_{3}$ ). The dehydrogenation, dehydrocyclization, and hydrocracking reaction were investigated with Iraqi heavy naphtha as a feedstock. The results showed that the conversion of paraffin's and naphthenes increases with increasing of reaction temperature and decreases with increasing of WHSV. María et al. [16] investigated the influence of the addition of $\mathrm{Pb}$ to $\mathrm{Pt}-\mathrm{Re} / \mathrm{Al}_{2} \mathrm{O}_{3}$ naphtha reforming catalysts. It was found that $\mathrm{Pb}$ interacts strongly with the (Pt-Re) active phase producing decay in the metal function activity. They concluded that the hydrogenolysis is more affected than dehydrogenation. They found that a part of the $\mathrm{Pb}$ is deposited over the support decreasing the acidity and the strength of the most acidic sites. 


\section{NO.10 Journal of Petroleum Research \& Studies ( JPR \& S)}

It is important to mention here that many previous studies on catalytic reforming process have focused on the use of n-hexane, n-heptane, and n-octane as feedstocks $[2,4,5,6$, and 10]. Also, it is clear that there is a little investigations about the use of trimetallic catalysts (Ge or In) supported on zeolite in catalytic reforming of heavy naphtha. On the other hand, the design, modification, and performance of reforming catalysts are required a detailed understanding of the reaction mechanism, and catalyst deactivation. Such information will lead to prepare a catalyst with reduced deactivation. Therefore, the present investigation aims to prepare and modify reforming catalysts using different types of promoters and investigate their performance using Iraqi-heavy as a feedstock. Then study the catalyst stability at different operating parameters of reforming process.

\section{Experimental Work}

\subsection{Materials and Apparatus}

Iraqi heavy petroleum naphtha delivered by Al-Dura Refinery was used as a feedstock in present investigation. The specifications and chemical analysis of Iraqi-heavy-naphtha are tabulated in tables (1) and (2) respectively. Pure hydrogen gas $(99.9 \%)$ was supplied from Al-Mansour plant-Baghdad. Hexachloroplatonic acid $\mathrm{H}_{2} \mathrm{PtCl}_{6}\left(40 \%\right.$ wt Pt) Germany, Indium nitrate In $\left(\mathrm{NO}_{3}\right) 3.5 \mathrm{H}_{2} \mathrm{O}$, Tin chloride $\mathrm{SnCl}_{2}$, and Germanium tetra chloride $\mathrm{GeCl}_{4}$ were supplied from Fluka.

Table (1) The specifications of Iraqi-heavy-naphtha Al-Dura Refinery (Baghdad)

\begin{tabular}{|r|l|l|}
\hline N0. & \multicolumn{1}{|c|}{ Specifications } & \multicolumn{1}{|c|}{ Measurement } \\
\hline 1 & API. at $15.6^{\circ} \mathrm{C}$ & 62.6 \\
\hline 2 & Sp.gr & 0.729 \\
\hline 3 & Sulfur Content & $<7 \mathrm{ppm}$ \\
\hline
\end{tabular}


NO.10 Journal of Petroleum Research \& Studies ( JPR \& S)

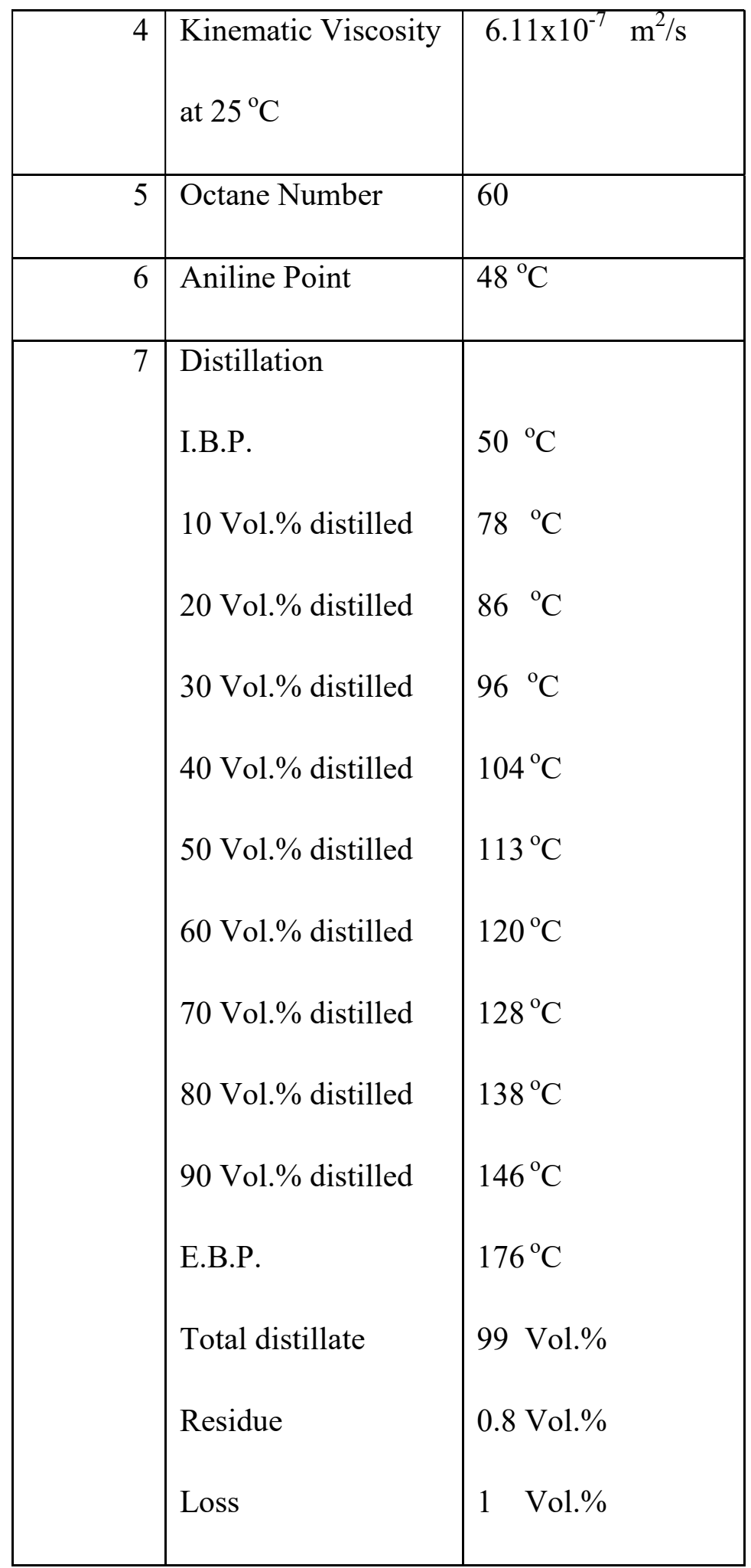


Table (2) The G.C. analysis of Iraqi-heavy-naphtha feedstock

\begin{tabular}{|c|c|c|}
\hline N0. & Compounds & Volume \% \\
\hline 1 & iso-pentane & 0.52 \\
\hline 2 & normal-pentane & 3.18 \\
\hline 3 & 2,2-dimehtyl butane & 4.65 \\
\hline 4 & 2,3-dimehtyl butane & 3.88 \\
\hline 5 & 2-mehtylpentane & 3.78 \\
\hline 6 & 3-mehtylpentane & 1.12 \\
\hline 7 & normal-hexane & 7.62 \\
\hline 8 & 2,2-dimehtyl pentane & 8.47 \\
\hline 9 & 2,3-dimehtyl pentane & 1.01 \\
\hline 10 & Benzene & 5.50 \\
\hline 11 & Cyclohexane & 4.41 \\
\hline 12 & normal-heptane & 17.8 \\
\hline 13 & Toluene & 4.42 \\
\hline 14 & normal-octane & 15.3 \\
\hline 15 & $+\mathrm{C} 8$ & 18.34 \\
\hline 16 & Total & $100 \%$ \\
\hline
\end{tabular}


NO.10 Journal of Petroleum Research \& Studies ( JPR \& S)

\subsection{Preparation of Reforming Catalysts}

In the present investigation four types of catalysts were prepared: $\mathrm{Pt} / \mathrm{HY}, \mathrm{Pt}-$ Sn/HY, Pt-Sn-In/HY, and Pt-Sn-Ge/HY. In order to modify the specification of $\mathrm{NaY}$ zeolite, the $\mathrm{Na}^{+}$ions were exchanged for $\mathrm{NH}^{4+}$ ions to obtain the $\mathrm{HY}$ by ion exchanging the original $\mathrm{NaY}$ zeolite with $(3 \mathrm{~N})$ ammonium chloride solution [3]. Thus $78.75 \mathrm{~g}$ of ammonium chloride in $500 \mathrm{ml}$ distillate water were contacted with $50 \mathrm{~g}$ of $\mathrm{NaY}$ zeolite with stirring for $1 \mathrm{hr}$ at $50{ }^{\circ} \mathrm{C}$. Then, the exchanging process continues for 4 days at laboratory temperature of $25{ }^{\circ} \mathrm{C}$ with $87 \%$ of exchanging rate of $\mathrm{Na}^{+}$by $\mathrm{NH} 4+$. After exchange, the sample $\mathrm{HY}$ was filtered, washed and dried at $110{ }^{\circ} \mathrm{C}$ for $10 \mathrm{hr}$. Then, the prepared sample was washed with deionized water to be free of chloride ions, and drying procedures were repeated twice. The obtained zeolites were calcined in air at $550{ }^{\circ} \mathrm{C}$ for 5 hours to obtain the $\mathrm{HY}$ form.

\subsubsection{Preparation of Pt/HY Catalyst}

The exchanged zeolite (HY) was loaded with Pt at concentrations of $0.5 \mathrm{wt} \%$ by impregnation process with aqueous solution of hexachloroplatonic acid $\mathrm{H}_{2} \mathrm{PtCl}_{6}$ with $40 \% \mathrm{Pt}$ [3]. The prepared solution was added dropwise to the zeolite with mixing for 4 hours at $25{ }^{\circ} \mathrm{C}$. The mixture was then left at room temperature for 24 $\mathrm{hr}$, it was stirred intermediately during this time. The mixture was then slowly evaporated to dryness over a period of $8 \mathrm{hr}$ at temperature of $75^{\circ} \mathrm{C}$. The resulting catalysts were dried in air at $110^{\circ} \mathrm{C}$ for an additional $12 \mathrm{hr}$. Then, the samples were calcined in air at $550^{\circ} \mathrm{C}$ for 10 hours (increasing to that temperature with a rate of $0.5^{\circ} \mathrm{C} / \mathrm{min}$ ) and finally reduced at $450^{\circ} \mathrm{C}$ in flowing $\mathrm{H}_{2}$ for $4 \mathrm{hr}$ at $\mathrm{H}_{2}$ flow of 60 $\mathrm{cm}^{3} / \min [8,9,15]$. Then, at this stage the samples are referred to as $\mathrm{Pt} / \mathrm{HY}$ catalyst. 


\subsubsection{Preparation of Pt-Sn/HY Catalyst}

The Pt-Sn/HY catalyst was prepared by co-impregnation by adding tin chloride $\left(\mathrm{SnCl}_{2} \cdot 2 \mathrm{H}_{2} \mathrm{O}\right)$ to the prepared $\mathrm{Pt} / \mathrm{HY}$ catalyst. Tin chloride was first dissolved in deionized water and heated for $30 \mathrm{~min}$ at $70{ }^{\circ} \mathrm{C}$. Then, tin chloride was added to the solution containing catalyst and leaving it without stirring for $1 \mathrm{hr}$ and then gently stirred for $1 \mathrm{hr}$ in water bath at $70{ }^{\circ} \mathrm{C}$. The resulting catalyst was dried at $120{ }^{\circ} \mathrm{C}$ for $12 \mathrm{hrs}$, and calcined in air at $550^{\circ} \mathrm{C}$ for $10 \mathrm{hr}$ (increasing to that temperature with a rate of $0.5^{\circ} \mathrm{C} / \mathrm{min}$ ) and finally reduced at $450^{\circ} \mathrm{C}$ in flowing $\mathrm{H}_{2}$ for $4 \mathrm{hr}$ at $\mathrm{H}_{2}$ flow of $60 \mathrm{~cm}^{3} / \mathrm{min}$, the final catalyst concentration was $0.5 \mathrm{wt} \% \mathrm{Pt}$, and $0.1 \mathrm{wt} \% \mathrm{Sn}[15]$.

\subsubsection{Preparation of Pt-Sn-Ge/HY and Pt-Sn-In/HY Catalysts}

On the other hand, the trimetallic catalysts Pt-Sn-Ge/HY, and Pt-Sn-In/HY were prepared by follow the same procedure that was conducted for the preparation of bimetallic catalyst, but using a third metal (Ge and In) with metals Pt-Sn/HY catalyst. Thus, it was used the Germanium tetra chloride $\mathrm{GeCl}_{4}\left(1.6 \mathrm{mg} \mathrm{Ge} . \mathrm{ml}^{-1}\right)$ and Indium nitrate $\mathrm{In}\left(\mathrm{NO}_{3}\right) 3.5 \mathrm{H}_{2} \mathrm{O}\left(2 \mathrm{mg} \mathrm{In.} \mathrm{ml}{ }^{-1}\right)$. These metal solutions added to the bimetallic Pt-Sn/HY catalyst. Then, each tri-metallic catalyst was dried at 120 ${ }^{\circ} \mathrm{C}$ for $12 \mathrm{hr}$, and calcined in air at $550^{\circ} \mathrm{C}$ for $10 \mathrm{hr}$ (increasing to that temperature with a rate of $0.5^{\circ} \mathrm{C} / \mathrm{min}$ ) and then, the catalyst reduced in flowing $\mathrm{H}_{2}$ for 4 hours at $450^{\circ} \mathrm{C}$ at $\mathrm{H}_{2}$ flow of $60 \mathrm{~cm}^{3} / \mathrm{min}$. Then, the final tri-metallic catalyst composition was $0.5 \mathrm{wt} \% \mathrm{Pt}, 0.1 \mathrm{wt} \% \mathrm{Sn}$, and $0.1 \mathrm{wt} \%$ of Ge or In.

\subsection{Reaction Apparatus and Procedure}

The catalysts performance of reforming process was investigated by designing and constructing an experimental pilot plant as shown in figure (1). On the other hand, figure (2) shows a schematic diagram of catalytic reforming unit. The 
NO.10 Journal of Petroleum Research \& Studies ( JPR \& S)

apparatus consisted of a vertical tubular stainless steel reactor of $20 \mathrm{~mm}$ internal diameter, $30 \mathrm{~mm}$ external diameter and $680 \mathrm{~mm}$ height. The reactor was heated uniformly using an electrical furnace. The reactor fitted with accurate means for control of pressure, gas and liquid flow rates. The temperature at the reactor center of the catalyst bed was determined and controlled by a temperature control system, which have a calibrated thermocouple sensor type K (iron-constantan).

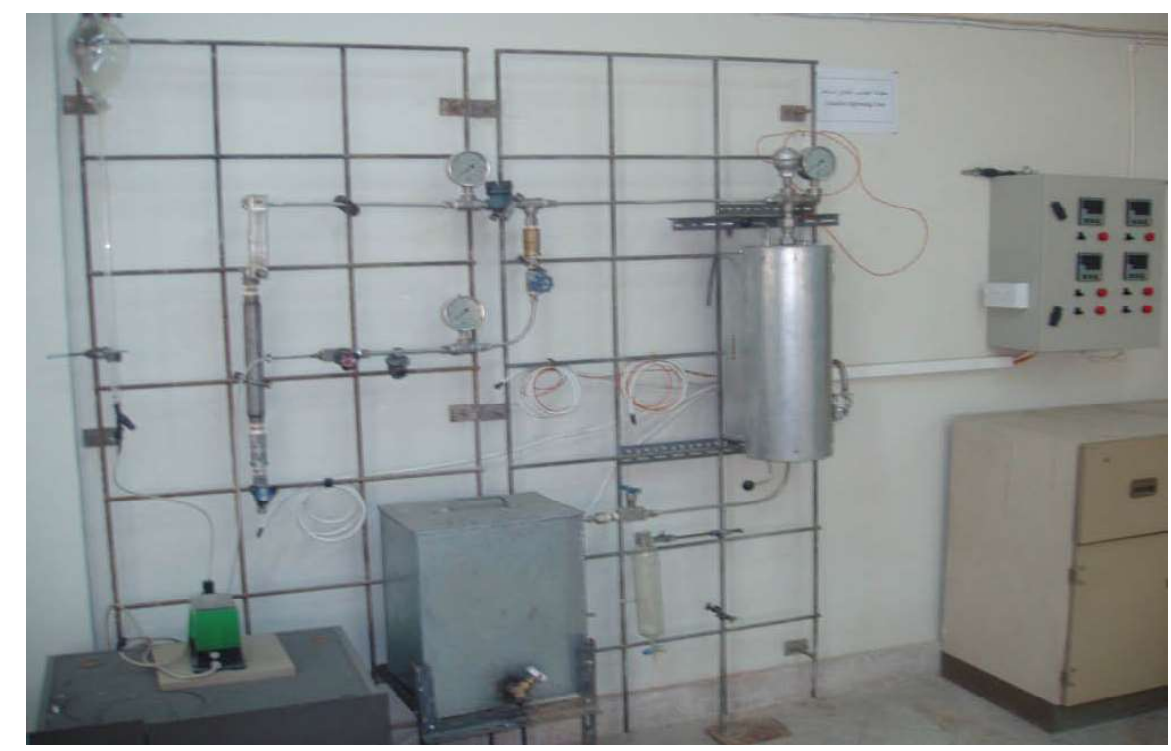

Fig. (1) General view of experimental catalytic reforming unit

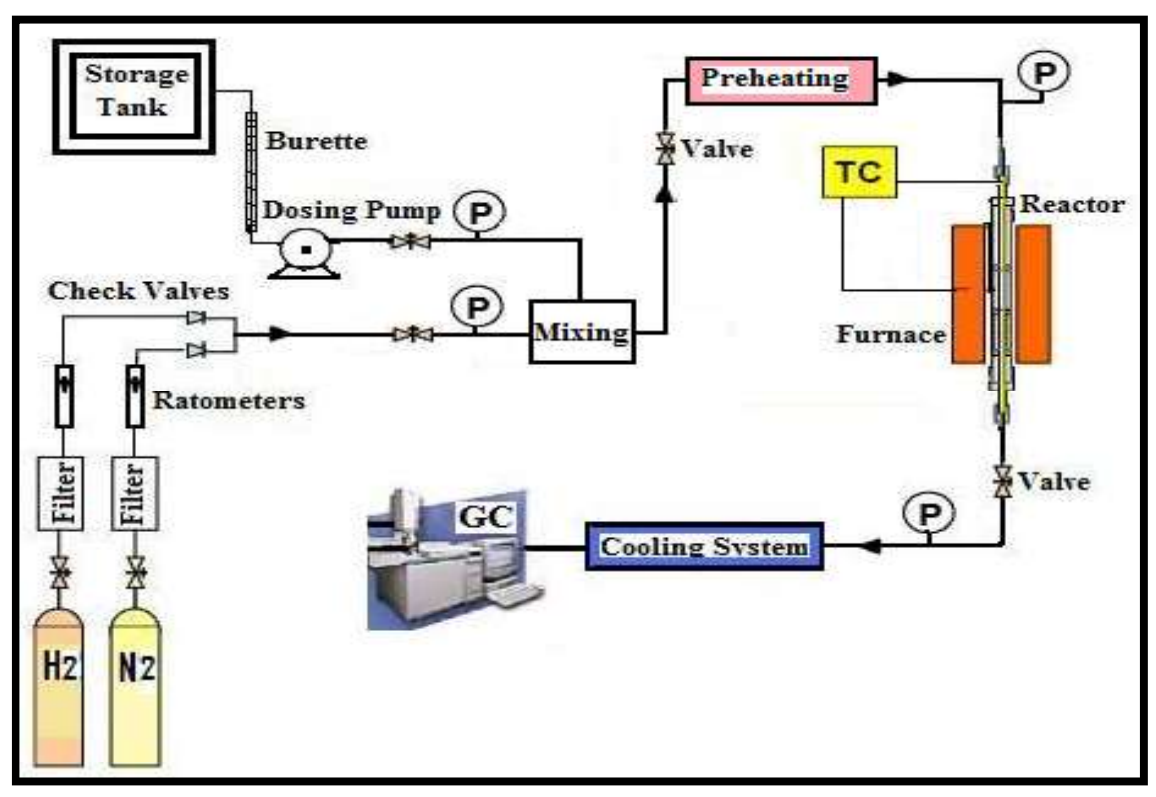

Fig. (2) Schematic diagram of catalytic reforming apparatus 


\section{NO.10 Journal of Petroleum Research \& Studies ( JPR \& S)}

The prepared catalyst was dried at $110{ }^{\circ} \mathrm{C}$ in $\mathrm{N}_{2}$ flow for $1 \mathrm{hr}$ and reduced at 450 ${ }^{\circ} \mathrm{C}$ in hydrogen flow for 4 hours. In each run $50 \mathrm{~g}$ of catalyst was charged into the reactor. The $\mathrm{WHSV}=2, \mathrm{H}_{2} / \mathrm{HC}$ molar ratio $=3$, were used for all experimental runs. The feed mixture of hydrogen and hydrocarbon was preheated to reactor temperature before entering the catalytic bed. The reaction was carried out at a temperatures varied between 425 to $525{ }^{\circ} \mathrm{C}$ with atmospheric pressure.

For each run, the reformate products were analyzed in a Gas Chromatograph type Shimadzu GC-2014 with FID using capillary column type S.G.E., length=25 $\mathrm{mm}, \mathrm{I} . \mathrm{D} .=0.22 \mathrm{~mm}, \mathrm{film}=0.2 \mu \mathrm{m}$, and using nitrogen gas as a carrier gas.

\section{Results and Discussions}

The main aim of the present investigation is to prepare modified catalysts through promoting their specifications using some types of promoters such as $\mathrm{Sn}$, In, and Ge. The advantage of the third metal is to inhibit or enhance the reactions bath ways of chemisorption, hydrogenolysis, and hydrogenation.

In operation of catalytic reforming, the compositional information of the feedstock and catalysts are required for monitoring, control, and selection of optimal process conditions. Therefore, in the present work, the chemical composition of the reformate is studied to ensure the control of the reforming process.

It is important to mention here that the catalysts investigated in the present work were dependent on the zeolite $\mathrm{Y}$ support. Zeolites are the alumina silicate (molecular sieve) in which has the capacity to selective adsorption of molecules based on pore diameter. Table (3) summarizes the general characterization and properties of prepared catalysts. The specific surface area of the catalysts BET, and the pore volume has been evaluated by $\mathrm{N} 2$ adsorption at $-196^{\circ} \mathrm{C}$. It is clear that all 
NO.10 Journal of Petroleum Research \& Studies ( JPR \& S)

the general properties of the four catalysts are the same with slightly variation. Obviously, the relatively high surface area of the Y-zeolite support $\left(420 \mathrm{~m}^{2} / \mathrm{g}\right)$ favors the dispersion of metallic particles on the external surface of the catalyst in comparison with classical A12O3 that posses a surface area of about $200 \mathrm{~m}^{2} / \mathrm{g}$.

Table (3) The specifications of the four prepared catalysts

\begin{tabular}{|c|c|c|c|c|c|}
\hline No. & Property & $\mathrm{Pt} / \mathrm{HY}$ & $\mathrm{Pt}-\mathrm{Sn} / \mathrm{HY}$ & Pt-Sn-In/HY & $\mathrm{Pt}-\mathrm{Sn}-\mathrm{Ge} / \mathrm{HY}$ \\
\hline 1 & Platinum content $(\mathrm{w}$ & {$\left[\begin{array}{ll}0.5 & \text { w } \\
\mathrm{Pt} & \end{array}\right.$} & $\begin{array}{ll}0.5 & \mathrm{wt} \% \\
\mathrm{Pt} & \\
\text { and } & 0.1 \% \\
\mathrm{Sn} & \end{array}$ & $\begin{array}{l}0.5 \mathrm{wt} \% \mathrm{Pt} \\
0.1 \% \mathrm{Sn}, \text { and } \\
0.1 \% \mathrm{In}\end{array}$ & $\begin{array}{l}0.5 \mathrm{wt} \% \mathrm{Pt} \\
0.1 \% \mathrm{Sn}, \text { and } \\
0.1 \% \mathrm{In}\end{array}$ \\
\hline 2 & Surface Area $\left(\mathrm{m}^{2} / \mathrm{g}\right)$ & 425 & 423 & 420 & 420 \\
\hline 3 & Pore Volume $\left(\mathrm{cm}^{3} / \mathrm{s}\right.$ & 0.6 & 0.6 & 0.56 & 0.55 \\
\hline 4 & Average Pore Size & 25 & 25 & 25 & 25 \\
\hline 5 & Chlorine Content (v & 0.3 & 0.3 & 0.3 & 0.3 \\
\hline 6 & Internal (Si/Al) & 1.6 & 1.6 & 1.6 & 1.6 \\
\hline
\end{tabular}

\subsection{Effect of Reaction Temperature}

The mole percentage of produced reformate from the conversion of heavy naphtha over the four types of prepared catalysts (Pt/HY, Pt-Sn/HY, Pt-Sn-Ge/HY, and Pt-Sn-In/HY) are shown in figures (3) to (6) as a function of reaction temperatures. The produced reformate come from aromatization, isomerization, and cracking reactions. Therefore, the results in the present work are shown in the 


\section{NO.10 Journal of Petroleum Research \& Studies ( JPR \& S)}

form of overall compounds of aromatics: (benzene, toluene, xylenes), branched isomers: (iso-C4, to iso-C9), n-paraffins: (n-C5 to n-C10), and naphthenes: (C6 to C9). Then figures (3) to (6) demonstrated that the reaction temperature is very dominated factor in controlling of the reformate products distribution.

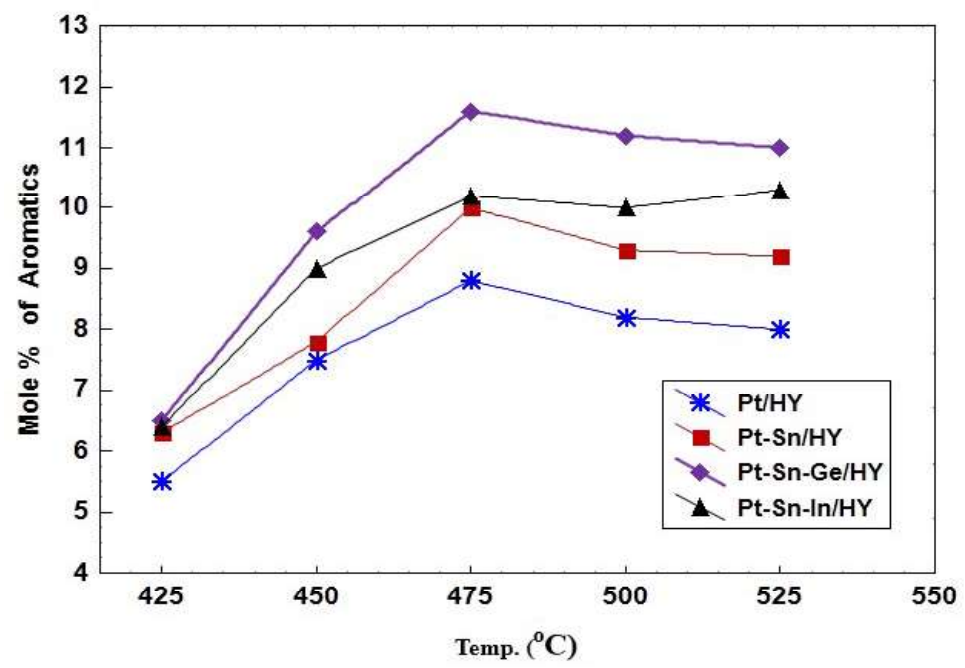

Fig. (3) The mole \% of produced aromatics for each catalyst as a function of temperature

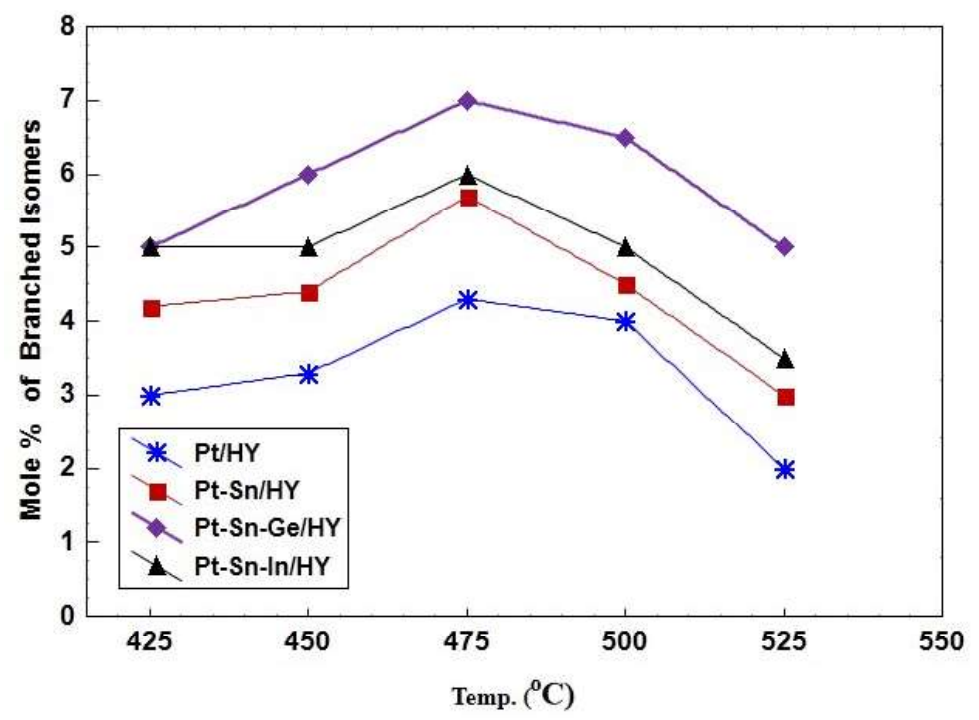

Fig. (4) The mole \% of branched isomers produced for each catalyst as a function of temperature 


\section{NO.10 Journal of Petroleum Research \& Studies ( JPR \& S)}

From figures (3) to (4) it was noted that the best reaction temperature of all catalyst types was $475^{\circ} \mathrm{C}$ in which give the highest conversion of heavy naphtha to desired products of aromatics and branched isomers. Also, according to these figures, it can be clearly noted that when trimatallic catalysts (Ge and In) a high concentration of aromatics and branched compounds are produced and then high RON gasoline. This approach is in agreement with the conclusion of Moljord et al. [10] who's found that the RON has a direct dependence on the existing aromatic in reformate content.

On the other hand, from the same figures it can note that the concentration of branched isomers is increased in compression with aromatics products. This behavior is agree with the more recently formulations to increase of the branched isomers to aromatics ratio in order to reduce the content of aromatic hydrocarbons in the fuel due to environmental regulations $[1,7]$.

It important to mention here that the cracking reaction be more effected at temperatures greater than $475^{\circ} \mathrm{C}$ Therefore, the results pointed to formation of low value products ( $\mathrm{C} 1-\mathrm{C} 4$ gases) with temperature increasing than $475^{\circ} \mathrm{C}$. On the other hand, the same figures pointed to that the addition of Ge and In (trimetallic catalysts: Pt-Sn-In/HY and Pt-Sn-Ge/HY) decrease the formation of low value products such as methane, ethane and propane. This conclusion is in agreement with the work of Maria et al. [14] and Shahrazad et al. [15]. 


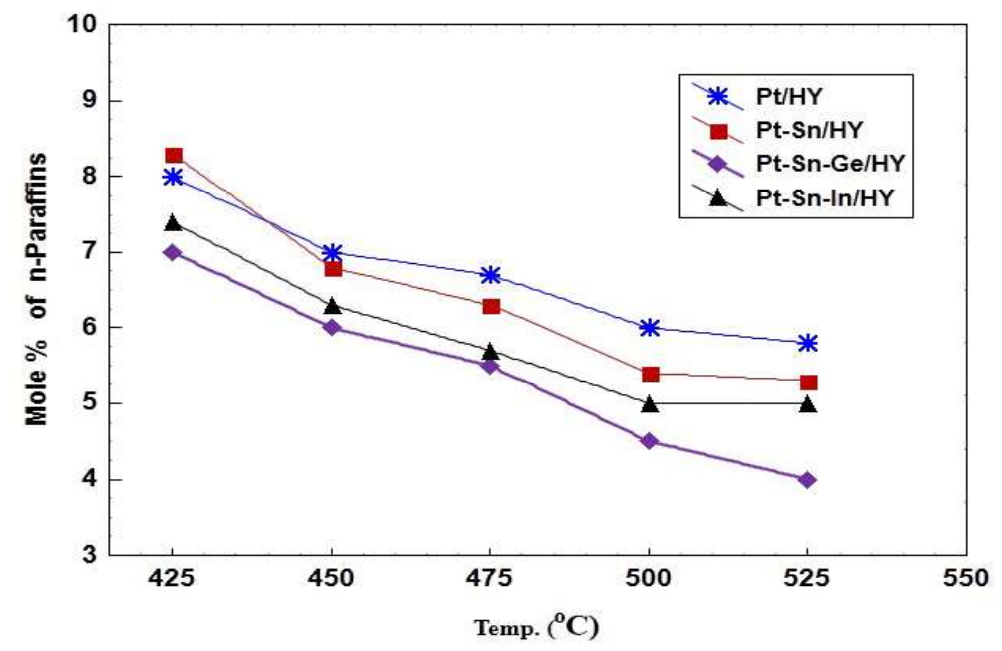

Fig. (5) The mole \% of n-Paraffin's produced for each catalyst as a function of temperature

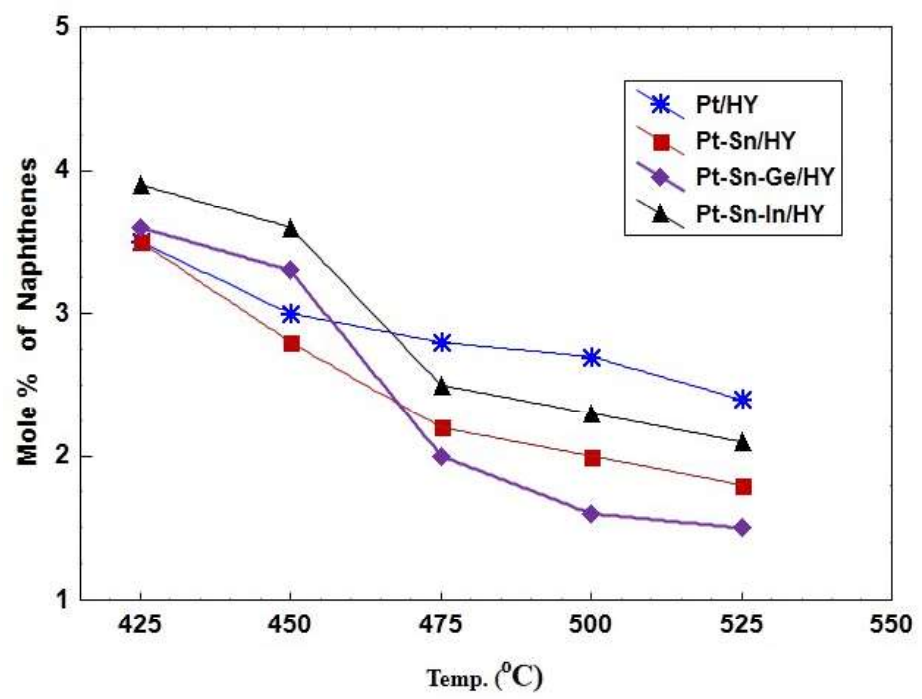

Fig. (6) The mole \% of produced naphthenes for each catalyst as a function of temperature.

\subsection{Effect of Reaction Time}

Figure (7) presents the relationship between the conversion of heavy naphtha and reaction time over the four types of prepared catalysts. All experiments were performed at $475^{\circ} \mathrm{C}, \mathrm{H} 2 / \mathrm{HC}=3$, and $\mathrm{WHSV}=2$. The catalytic activity was tested on stream over a period of $40 \mathrm{hr}$ of reaction time on stream.

The results show that the fresh catalysts exhibit the highest initial heavy naphtha conversion. In this situation, the total conversion was $81 \%$ for Pt-Sn-In/HY, 74\% 
NO.10 Journal of Petroleum Research \& Studies ( JPR \& S)

for Pt-Sn-Ge/HY, 57\% for Pt-Sn/HY, and 48\% for Pt/HY. Then, the catalysts activities decreased gradually with time due to the carbon depositions that produced during the reaction. In this case the coke formation can cover the active sites of the catalysts, thus decreasing the catalytic activity. These results are agreed with the work of Jorge et al. [8] and María et al. [16].

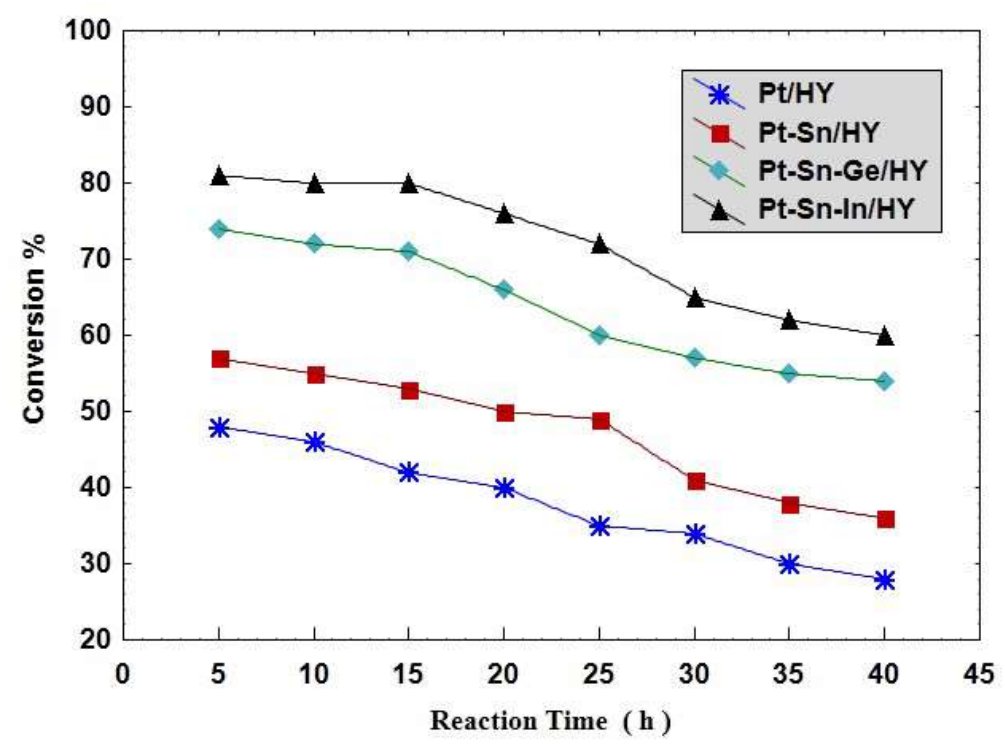

Fig. (7) The percentage of total heavy naphtha conversion as a function of reaction time Reaction conditions: $475^{\circ} \mathrm{C}, \mathrm{H}_{2} / \mathrm{HC}=3$, and WHSV $=2$

It is important to mention here that the dehydrogenation and hydrogenolysis are supposed to occur over metallic sites, while isomerization occurs over acid sites. Dehydrocyclisation and aromatization reactions present a bifunctional mechanism. On the other hand, in the reforming process, there is a substantial difference in the rate between particular reactions. Thus, the hydrogenation of naphthenes to aromatic hydrocarbons runs at a rate, which is by two orders of magnitude faster than the rate with which paraffins are dehydrocyclized to naphthenes $[5,12]$. Therefore, in the preparation of reforming catalysts, a careful balance must be maintained between the hydrogenation and dehydrogenation functions of the metals and the support. 
Figure (8) shows the relationship between the total selectivity of desired products (aromatics and isomers) with reaction time (time on stream) over the four prepared catalysts. The results pointed to that the trimatellic catalysts $(\mathrm{Pt}-\mathrm{Sn}-\mathrm{In} / \mathrm{HY}$ and Pt$\mathrm{Sn}-\mathrm{Ge} / \mathrm{HY}$ ) give the highest selectivities and stabilities with low coking formation in comparing with monometallic and bimetallic catalysts. The initial catalysts selectivties (up to $10 \mathrm{hr}$ ) for Pt-Sn-In/HY, Pt-Sn-Ge/HY, Pt-Sn/HY, and Pt/HY were $91.5 \%, 85 \%, 79 \%$, and $74 \%$ respectively.

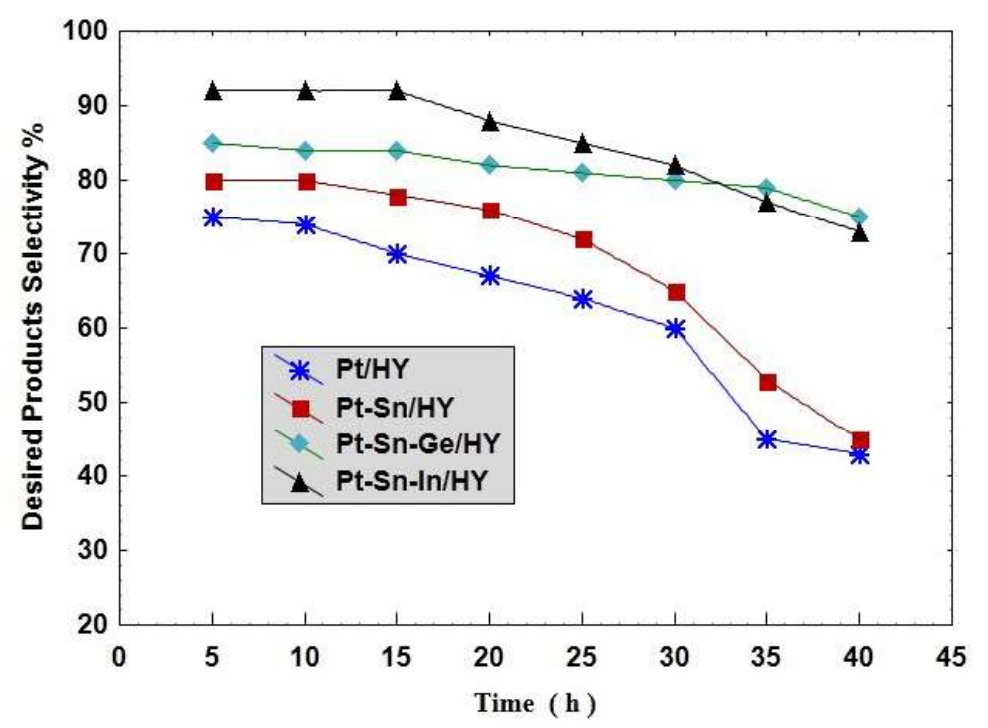

Fig. (8) The total selectivity of desired products as a function of time at reaction temperature of $475^{\circ} \mathrm{C}, \mathrm{H}_{2} / \mathrm{HC}=3$, and $\mathrm{WHSV}=2$

In general, the decrease in catalysts selectivity relates to a decrease in catalyst surface area due to carbon formation that block the active sits of both metals and acid site. The accumulation of the coke with time will be reducing the properties of the catalyst and then the selectivity to desired products. The same results are shown by Carlos et al. [13] and Shahrazad et al. [15]. It is important to mention here that the coke deposition regards as the more challenging problem on reforming catalysts, which leads to loss activity, selectivity, life time, and yield. The coke deposition induces a decrease of the amount of strong Lewis and 
NO.10 Journal of Petroleum Research \& Studies ( JPR \& S)

Brønsted acid sites. This decrease of the amount of strong Lewis acid sites involves an increase in the isomer yield.

On the other hand, according to explanation of Ponec and Bond [17] the introducing of a second or third metal (such as Ge, In,) would divide the metal surface into smaller islands, preventing thus polymerization of unsaturated intermediates to form a two-dimensional layer of potential coke precursors. Also, from the results of figure (8) it can be noted that the presence of In and Ge decrease the hydrogenolysis function of the catalysts with reaction time. Therefore, the In, and Ge trimetallic catalysts showed the highest selectivity and resistant against deactivation under the operational conditions. Then, the Pt-Sn-In/HY catalyst have a higher selectivity to branched isoparaffins, while, a reformate rich in aromatics can be obtained over Pt-Sn-Ge/HY catalyst as shown in figures (3) and (8). 


\section{Conclusions}

1- The addition of germanium or indium as a third metal to the bimetallic catalyst $\mathrm{Pt}-\mathrm{Sn} / \mathrm{HY}$ improves the metal side and acid site of the prepared catalyst. The third metal reduces the hydrogenolytic activity of the bimetallic catalyst.

2- The results showed that the best reforming temperature over all prepared types of catalysts was $475^{\circ} \mathrm{C}$ which gave the highest conversion of heavy naphtha to aromatization and isomerization products with low cracking products.

3- It was noted that the catalysts selectivities to aromatics and isomers products were improved through the addition of the Ge and In metals. The trimetallic catalyst Pt-Sn-In/HY and Pt-Sn-Ge/HY show high selectivity to desired products of $91.5 \%$ and $85 \%$ respectively. On the other hand, the $\mathrm{Pt}-\mathrm{Sn} / \mathrm{HY}$ and $\mathrm{Pt} / \mathrm{HY}$, catalysts show slectivities of $79 \%$ and $74 \%$ respectively.

4- The trimetallic catalysts showed higher stability than the mono and bi-metallic catalysts because of the reduction of polymerization reaction of unsaturated intermediates that converted to coke precursors.

5- Then, the Pt-Sn-In/HY catalyst have a higher selectivity to branched isoparaffins, while, a reformate rich in aromatics can be obtained over the and Pt-Sn-Ge/HY catalyst, with low concentration of cracking products. 
NO.10 Journal of Petroleum Research \& Studies ( JPR \& S)

\section{References}

1. Vanina A. M., Javier M. G., Juan C. Y., Carlos R. V., Carlos L. P.; "Influence of Additives on the Pt Metal Activity of Naphtha Reforming Catalysts" Applied Catalysis A: General, Vol. 354, Iss 1-2, 15 Feb.,161-168 (2009).

2. Mohammad R. R., Mitra J., Davood I.; "Progress in catalytic naphtha reforming process: A Review", Applied Energy, Vol. 109, 79-93 (2013).

3. Gates B.C., Katzer J.R. and Schuit G.C.A., "Chemistry of Catalytic Processes", McGraw-Hill, N. York, (1979).

4. Jabir Shanshool and Khalid A. Sukkar; "Modification and Characterization of Platinum Supported Y-Zeolite Catalyst", Proceeding of Jordon Int. Chem. Eng. Conference III, Vol. 2, Sep., 753-762 (1999).

5. Meyers R.A.;" HandBook of Petroleum Refining Processing”, McGraw Hill, 3rd Edition, USA, (2006).

6. Abdul Halim A.K. Mohammed, Rawa G. Yousuf, Karim K. Esgair; "Cracking Activity of Prepared Y-Zeolite Catalyst Using Cumene on Fluidized Bed Reactor", Iraqi J. of Chem. and Petrol. Eng., Vol.12 No.2, 9 17 (2011).

7. Silvana A. D’Ippolito, Carlos R. Vera, Florence Epron, Catherine Especel, Patrice Marécot, Carlos L. Pieck; "Naphtha reforming Pt-Re-Ge $/ \gamma-\mathrm{Al}_{2} \mathrm{O}_{3}$ catalysts prepared by catalytic reduction: Influence of the $\mathrm{pH}$ of the $\mathrm{Ge}$ addition step", Catalysis Today, Vol. 133, 13-19 (2008).

8. Jorge, N., Timothy, J., Ravindra D.; "Kinetics of Deactivation of Bifunctional Pt/ $\mathrm{Al}_{2} \mathrm{O}_{3}$-Cl Catalysts by Coking", AIChE, Vol.37, No. 6, 845854, June, (1991). 


\section{NO.10 Journal of Petroleum Research \& Studies ( JPR \& S)}

9. Carter J.L., McVinker G.B., Weissman W., Kmak M.S., Sinfel J.H.; "Bimetallic catalysts; application in catalytic reforming", Applied Catalysis, Vol. 3, Issue 4, 15 August, 327-346 (1982).

10. Moljord K., Hellenes H.G., Hoff A., Tanem I., "Effect of Reaction Pressure on Octane Number and Reformate and Hydrogen Yields in Catalytic Reforming”, Industrial \& Engineering Chemistry Research, Vol. 35, 99-105, (1996).

11. Sunita R. B., Prem P., Gupta J.K., Sharma L.D., Murali G. D., Prasada T.S.R.; "Relationship Between Acidity and Catalytic Activity of $\mathrm{Al}_{2} \mathrm{O}_{3}-\mathrm{Cl}$ Supported Pt-Sn Catalysts", Studies in Surf. Sci. and Catal., Vol. 113, 365373, (1998).

12. Hughes T.R., Jacobson R.L., Tamm P.W.; "Catalytic Processes For Octane Enhancement By Increasing the Aromatics Content of Gasoline", Studies in Surface Science and Catalysis, Vol. 38, 317-333, (1988).

13. Carlos L. Pieck, Carlos R. Vera, Jose' M. Parera, Gustavo N. Gime'nez, Luciano R. Serra, Luciene S. Carvalho, Maria C. Rangel; "Metal Dispersion and Catalytic Activity of Trimetallic Pt-Re-Sn/ $\mathrm{Al}_{2} \mathrm{O}_{3}$ Naphtha Reforming Catalysts", Catalysis Today Vol. 107-108，637-642,(2005).

14. Maria A. V., Catherine E., Viviana M. B., Florence E., Carlos L. P.; "Influence of Gallium on the Properties of Pt- $\mathrm{Re} / \mathrm{Al}_{2} \mathrm{O}_{3}$ Naphtha Reforming Catalysts", Applied Catalysis A: General 407 49- 55, (2011).

15.Shahrazad R. Raouf, Khalid A. Sukkar, and Ramzy S. Hamied, "Heavy Naphtha Reforming Reactions with Trimetallic Catalysts: Experimental and Analytical Investigation", Eng. and Tech. J., Vol.29, No.10, 1917-1935, (2011) 
NO.10 Journal of Petroleum Research \& Studies ( JPR \& S)

16. María A. S., Vanina A. M., Javier M. G., Juan C. Y., Carlos L. P.; "Catalytic Activity of Pt-Re- $\mathrm{Pb} / \mathrm{Al}_{2} \mathrm{O}_{3}$ Naphtha Reforming Catalysts", Journal of Chem. Tech. and Biotech., Vol. 86, Issue 9, 1198-1204, Sep. (2011).

17. Ponec V. and Bond G. C.; "Catalysis by Metals and Alloys", Stud. Surf. Sci., Catal., Elsevier, Amsterdam, (1995). 